\title{
Measurement of lgE to purified sesame storage proteins in sera from sesame allergic Japanese children
}

\author{
Peter Brostedt ${ }^{1 *}$, Sigrid Sjölander ${ }^{1}$, Cecilia Ericson ${ }^{1}$, Anette Holtz $^{1}$, Raimo Carlsson', Komei Ito ${ }^{2}$ \\ From Food Allergy and Anaphylaxis Meeting 2011 \\ Venice, Italy. 17-19 February 2011
}

\section{Background}

The storage proteins from sesame seed, $11 \mathrm{~S}$ globulin, $7 \mathrm{~S}$ vicilin and $2 \mathrm{~S}$ albumin, are official WHO/IUIS allergens. However, little is known about the IgE reactivity to the individual sesame allergen components.

\section{Objective}

To investigate the IgE reactivity to purified sesame storage proteins in sera from sesame allergic Japanese children.

\section{Methods}

The three storage proteins were all purified from unpolished sesame seeds extracted at $\mathrm{pH} 7,5$. The $11 \mathrm{~S}$ globulin and the 7S vicilin were enriched by precipitation in water. Pure $11 \mathrm{~S}$ globulin was obtained by a further precipitation with $35 \%$ ammonium sulfate followed by anion exchange chromatography. Pure 7S vicilin was obtained by adding gel filtration and anion exchange chromatography. The $2 \mathrm{~S}$ albumin was purified by cation exchange chromatography and gel filtration. Identities were confirmed by MALDI-TOF analysis. The three purified storage proteins were conjugated to the ImmunoCAP ${ }^{\circledR}$ matrix and quantitative IgE responses in sera from five sesame allergic Japanese children were measured.

\section{Results}

All the sera from sesame allergic Japanese children showed specific IgE reactivity to sesame extract. Out of the five sera, four had IgE response to $11 \mathrm{~S}$ globulin, all five to $7 \mathrm{~S}$ vicilin and three to $2 \mathrm{~S}$ albumin.

Phadia AB, Uppsala, Sweden

Full list of author information is available at the end of the article

\section{Conclusions}

IgE reactivity to all three storage proteins in sesame seed, $11 \mathrm{~S}$ globulin, $7 \mathrm{~S}$ vicilin and $2 \mathrm{~S}$ albumin, was shown in sera from the sesame allergic Japanese children.

\section{Author details}

${ }^{1}$ Phadia AB, Uppsala, Sweden. ${ }^{2}$ Aichi Children's Health and Medical Center, Department of Allergy, Obu, Japan.

Published: 12 August 2011

doi:10.1186/2045-7022-1-S1-P2

Cite this article as: Brostedt et al:: Measurement of IgE to purified

sesame storage proteins in sera from sesame allergic Japanese children. Clinical and Translational Allergy 2011 1(Suppl 1):P2.

Submit your next manuscript to BioMed Central and take full advantage of:

- Convenient online submission

- Thorough peer review

- No space constraints or color figure charges

- Immediate publication on acceptance

- Inclusion in PubMed, CAS, Scopus and Google Scholar

- Research which is freely available for redistribution

Submit your manuscript at www.biomedcentral.com/submit
() Biomed Central 